\title{
紫外線硬化樹脂点字の新規作成装置を用いた触読し易い点字縦横間隔の評価
}

\author{
土井 幸輝 ${ }^{* 1}$ ，西村 崇宏*1，河野 勝*2，梅沢 侑実*3 \\ 松森 ハルミ*3，和田 勉 ${ }^{* 4}$, 藤本 浩志 ${ }^{* 5}$
}

\section{Evaluation of the Transparent-Resinous-Ultraviolet-Cured-Type (TRUCT) Braille readability with focus on vertical and horizontal Braille dot distances by use of new printing device for TRUCT Braille}

\author{
Kouki DOI*1 ${ }^{*}$, Takahiro NISHIMURA*1 ${ }^{*}$, Masaru KAWANO ${ }^{* 2}$, Yumi UMESAWA ${ }^{* 3}$, \\ Harumi MATSUMORI ${ }^{* 3}$, Tsutomu WADA ${ }^{* 4}$ and Hiroshi FUJIMOTO*5 \\ ${ }^{{ }^{*} 1,{ }^{*} 2}$ Department of Education Information, National Institute of Special Needs Education \\ 5-1-1 Nobi, Yokosuka-shi, Kanagawa 239-8585, Japan \\ ${ }^{*}$ Graduate School of Human Sciences, Waseda University \\ 2-579-15 Mikajima, Tokorozawa-shi, Saitama 359-1192, Japan \\ ${ }^{* 4}$ The Japan Braille Library \\ 1-23-4 Takadanobaba, Shinjuku-ku, Tokyo 169-0075, Japan \\ ${ }^{* 5}$ Fuculty of Human Sciences, Waseda University \\ 2-579-15 Mikajima, Tokorozawa-shi, Saitama 359-1192, Japan
}

Received 6 July 2015

\begin{abstract}
Braille is a well-known communication tool for the visually impaired. In recent years, as a result of advances in Braille printing technology, the use of transparent resinous ultraviolet cured type (TRUCT) Braille has spread rapidly. As one of the most popular Braille printing technologies, the screen printing method is applied for printing TRUCT Braille. However, the screen printing method produces TRUCT Braille prints of poor quality. In this study, in order to improve the printing quality, we created a device for printing TRUCT Braille. Additionally, we evaluated TRUCT Braille readability for Braille beginner readers by focusing on horizontal and vertical Braille dot distances using our created device. From this study, we found that it was easy to print TRUCT Braille using our device. Braille beginner readers found it easy to read TRUCT Braille with adequate horizontal and vertical Braille dot distances. These findings support the use of TRUCT Braille for new Braille beginner textbooks, as well as for printing Braille signs in public facilities.
\end{abstract}

Key words : Human engineering, Human interface, Welfare engineering, TRUCT Braille, Visually impaired, Printing device, Vertical and horizontal Braille dot distance, Readability

\section{1. 緒言}

2014 年 1 月に我が国は，障害者の権利に関する条約（障害者権利条約）に批准し，2014 年 2 月に国際連合事務 局にて承認された。このような社会的背景を受けて，我が国でも，障害児・者に対する合理的配慮や支援技術の 更なる進展が期待されている，その一つとして，外界からの情報の多くを取得する感覚器である視覚に障害のあ る視覚障害児・者への支援技術については，更なる進展が求められている状況である.

視覚障害児・者への支援技術として古くから普及しているものの一つに，点字がある．点字は視覚障害児・者 が独自のペースで読み書きすることのできる感覚代行ツールであり，情報入手ツールとして視覚障害児・者の社

No.15-00381 [DOI:10.1299/transjsme.15-00381], J-STAGE Advance Publication date : 5 November, 2015

*1 正員，国立特別支援教育総合研究所 教育情報部（干239-8585 神奈川県横須賀市野比 5-1-1）

*2 国立特別支援教育総合研究所 教育情報部

*3 早稲田大学大学院 人間科学研究科（厂359-1192 埼玉県所沢市三ヶ島 2-579-15)

*4 日本点字図書館 総務課（干169-0075 東京都新宿区高田馬場 1-23-4）

*5 正員, 早稲田大学 人間科学学術院

E-mail of corresponding author: doi@nise.go.jp 
Doi, Nishimura, Kawano, Umesawa, Matsumori, Wada and Fujimoto, Transactions of the JSME (in Japanese), Vol.81, No.831 (2015)

会的自立を支援する重要な役割を担っている。これまで，点字は紙の上に打刻してそれを指先で読み取る紙製の 点字が一般的に利用されてきた．しかし，あらゆる分野の製品やサービスに対して高齢者や障害者が使いやすく なるよう配慮を求める国際標準 ISO/IEC ガイド 71（規格作成における高齢者・障害者のニーズへの配慮ガイドラ イン）が 2001 年 11 月に制定されたことを受けて，スクリーン印刷方式による無色透明な紫外線硬化樹脂を用い た点字（以下，紫外線硬化樹脂点字）が一般印刷物上へ付されるようになり，紫外線硬化樹脂点字の普及が期待 されるようになった．紫外線硬化樹脂点字は，上述のように無色透明であるが故に晴眼者が利用する墨字の上に も付すことができるため, 睛眼者と視覚障害児・者が一つの印刷物の情報を共有することができるという利点が ある. さらに, 紫外線硬化樹脂点字は, 紙製の点字と比較して耐久性が高く, 指先に伝わる点字の凸点の刺激も 強いために触読性にも優れている. また, スクリーン印刷方式による紫外線硬化樹脂点字は, 紙やプラスチック, 金属等の様々な素材に印刷することが可能である. なお, スクリーン印刷方式は印刷条件によって点の厚盛り（高 さ）不足やインクの滲みが生じるといった技術的な改善の余地はあるものの，このような利点を備えた紫外線硬 化樹脂点字は, 上述した国際標準 ISO/IEC ガイド 71 制定の後押しを受けて, 公共施設の案内図や食品のパッケー ジや生活用品等に墨字とともに併記されるようになり，我々の日常生活にも広く浸透しつつある.

このように，公共施設や日用生活用品に紫外線硬化樹脂点字が広く普及しつつある一方で，点字の識字率その ものは決して高くないといわれている，視覚障害児・者の点字習得状況について，2006 年 3 月に厚生労働省が公

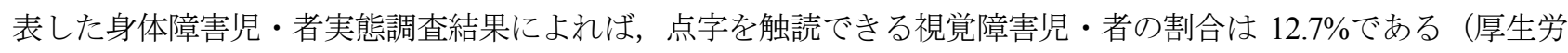
働省，2006）。この背景には，点字の触読性に関する客観的な知見が十分には揃っておらず，これから点字を習得 しょうとする点字触読初心者にとって点字を習得するためのハードルが依然として高いことが一つの要因となっ ている. 点字の 1 文字は 6 点で構成されており，3 行 $\times 2$ 列の点の有無の組み合わせによる点字パターンによっ て表現されるが，点字の触読性に影響を及ぼす文字サイズ (点間隔・高さ), 文字間隔（マス間隔），行間隔（図 1）については，紫外線硬化樹脂点字の品質に関する日本工業規格（JIS T9253（紫外線硬化樹脂インキ点字一品 質及び試験方法一)）（日本規格協会，2004）の中でも推奨サイズが規定されており，紫外線硬化樹脂点字製作を 手掛ける印刷メーカーが点字を付寸際の基準となっている.しかし，この JIS T9253で制定された紫外線硬化樹 脂点字パターンの推奨サイズは，日常的に点字を利用している点字熟達者を想定したこれまでの経験則に基づい て作成されたものである．実際に，点字指導に関わる教員からは，点字触読初心者にとって読み易い点字パター ンの推奨サイズを明らかにしてほしいとの要望が数多く挙がっている.さらに，工業標準化法では，日本工業規 格が制定もしくは確認, 改正された日から少なくとも 5 年を経過するまでにその内容を見直すことになっている. そのため, 規格見直しの際にエビデンスとして必要となる点字の触読性に関する客観的なデータの獲得は, 必要 不可欠な研究課題である.

点字の触読性に関する研究について, 紙製の点字に関しては, 点字触読初心者にとって読夕易い文字サイズ (点 間隔，高さ）や文字間隔（マス間隔，行間隔）を明らかにするための研究がなされてきた（林他，2003）（渡辺他， 2011). しかし, 紙製の点字とは触感も異なり, 凸点の刺激も指先により強く伝わる紫外線硬化樹脂点字について は，点字触読初心者を対象とした研究はほとんど行われていない。このような状況の中，筆者らは紫外線硬化樹 脂点字の読み易い点字パターンを明らかにするための研究を行ってきた．紫外線硬化樹脂点字の触読性に影響を 及ぼす主な点字の構成因子には，文字サイズ（点間隔，高さ）と文字間隔（マス間隔，行間隔）がある（図 1). このうち，紫外線硬化樹脂点字の点間隔，高さ，マス間隔については，それぞれ実験的な制約はあるものの触読 性評価実験によって点字触読初心者にとっても読み易いパターンを調べてきた（土井他, 2004, 2006, 2014). しか し, これらの先行研究（土井他，2004）における点間隔の評価研究では, 実験条件数の制約から, 縦と横の点間 隔の比率が 1 対 1 のパターンのみの評価しか行っていなかった。一方で, 触読し易い点間隔については縦と横の 点間隔が同じ比率の組合せとは限らない. 実際, JIS T9253においては, 縦と横の点間隔について異なる数值の規 定が設けられている．また，点字触読時には，人差し指を左から右だけでなく，同時に前後にも滑らせながら触 読するため, 触読し易い点間隔については縦と横で個別の值が存在すると考えられる. しかしながら, 紫外線硬 化樹脂点字の点間隔について, 縦と横の点間隔に着目して点字の触読性を評価した事例はない．また，点字触読 初心者にとって読み易い縦横の点間隔を明らかにした先行研究も筆者らが知る限り見当たらない. また，紫外線 硬化樹脂点字の印刷技術としては, 最も普遍的で印刷業者が新たな設備投資をせずに手掛けられるスクリーン印 刷方式が主流であるが，上述の通り，印刷条件によっては点の厚盛り不足やインクの滲みが生じるため，これら 
Doi, Nishimura, Kawano, Umesawa, Matsumori, Wada and Fujimoto,
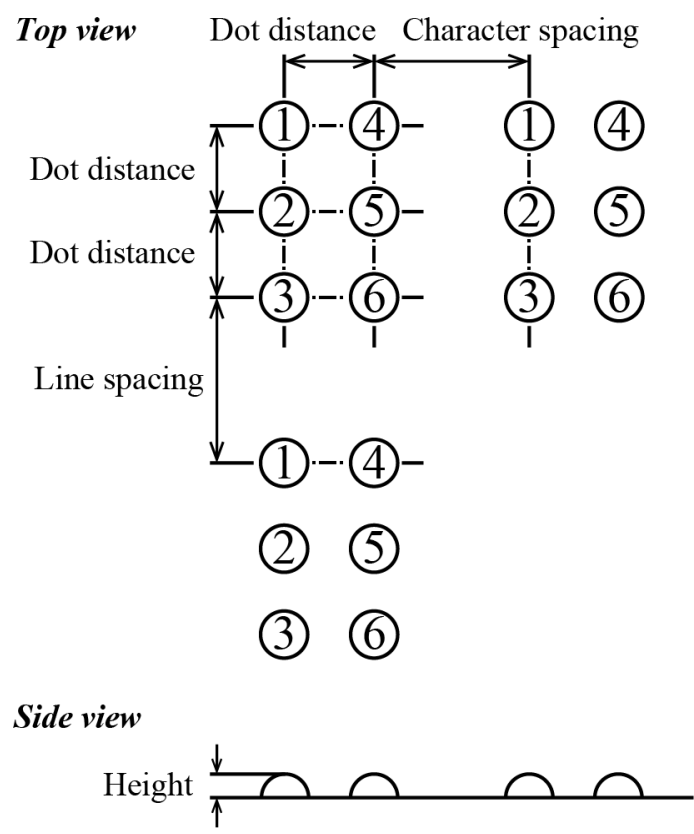

Fig. 1 Character size (height, dot distance), character spacing, and line spacing of Braille.

を技術的に改善していくことも課題である，具体的には，紫外線硬化樹脂点字の従来の作成方式であるスクリー ン印刷方式では JIS T9253 で規定された 0.4 $\pm 0.1 \mathrm{~mm}$ という点字の高さで安定して作成することが難しい.

以上より, 本研究では, スクリーン印刷方式の技術的課題への対応及び点字触読初心者が触読し易い紫外線硬 化樹脂点字パターン（縦横点間隔）を明らかにすることを目的として，新たな紫外線硬化樹脂点字の新規作成装 置の製作及び紫外線硬化樹脂点字の縦横点間隔が触読性に及ぼす影響を評価することにした．具体的に，新規作 成装置の製作については，厚盛りが可能で仕上がりの良い新たな紫外線硬化樹脂点字作成装置として，JIS T9253 に示される点字の高さの推奨值で安定して点字を作成可能な装置を製作し，その装置を用いて実験に必要な提示 刺激を作成することにした，そして，点字の触読に不慣れな点字触読初心者にとって読み易い縦横点間隔の条件 を明らかにするために，点字触読初心者を想定した点字の触読経験がない睛眼者を対象とした紫外線硬化樹脂点 字の触読性評価実験を実施した。

\section{2. 紫外線硬化樹脂点字の新規作成装置の製作}

本研究では, 点字触読初心者が触読し易い紫外線硬化樹脂点字の縦横点間隔を明らかにするために，実験に必 要な点間隔や高さを統制した提示刺激を用意する必要がある．しかし．既存のスクリーン印刷方式では，製版す る際の版厚や製版時に空けるドット径を高精度に統制することができないため，紫外線硬化樹脂点字の高さを統 制することができない．具体的には，スクリーン印刷方式では JIS T9253で規定された $0.4 \pm 0.1 \mathrm{~mm}$ という点字の 高さで安定して作成することが難しい，加えて，点間隔を複数条件設定した提示刺激を多数用意するためには， 製版に多くの時間を要する，そこで本研究では，スクリーン印刷方式に代わる新たな紫外線硬化樹脂点字の作成 装置を製作することにした，そして，製作した装置を用いて，次章で述べる紫外線硬化樹脂点字の触読性評価実 験で設定する点間隔や高さの紫外線硬化樹脂点字が作成できるかどうかを確認した.

\section{$2 \cdot 1$ 装置の概要}

本研究では, スクリーン印刷方式の問題点を改善寸る紫外線硬化樹脂点字の作成装置を新たに製作した (図 2). 本装置では，紫外線硬化樹脂インクを被印刷物に非接触で位置決めした状態で噴射する方法を採用した（図 3 ）。 この方式は，高精度に紫外線硬化樹脂インクを塗布できることに加え製版を必要としないため，スクリーン印刷 方式よりも本実験の提示刺激作成に向いている，本装置では，JIST9253 の耐久性試験を満たす紫外線硬化樹脂イ 
Doi, Nishimura, Kawano, Umesawa, Matsumori, Wada and Fujimoto, Transactions of the JSME (in Japanese), Vol.81, No.831 (2015)

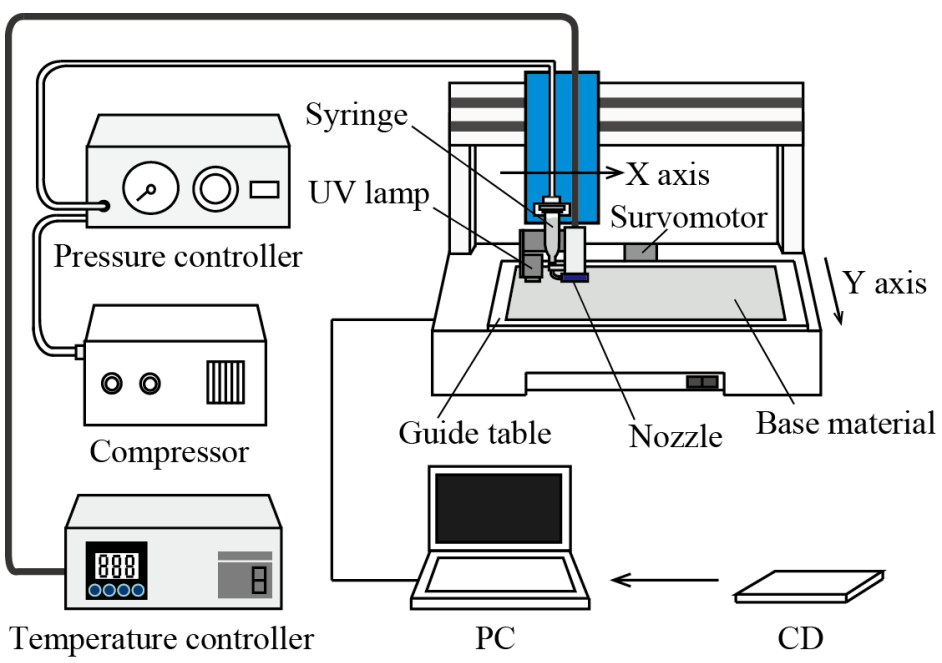

Fig. 2 Illustration of developed printing device for TRUCT Braille.

(1)

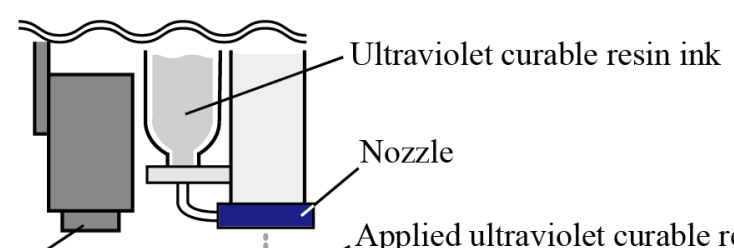

Ultraviolet curable resin ink is jetted from non-contact nozzle.

UV lamp

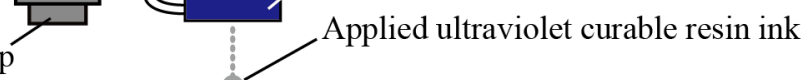

Base material

(2)
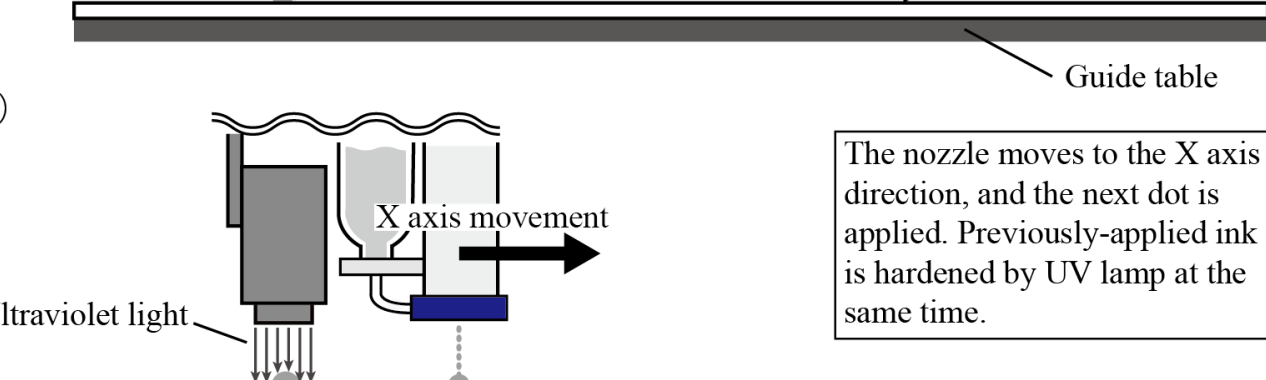

(3)

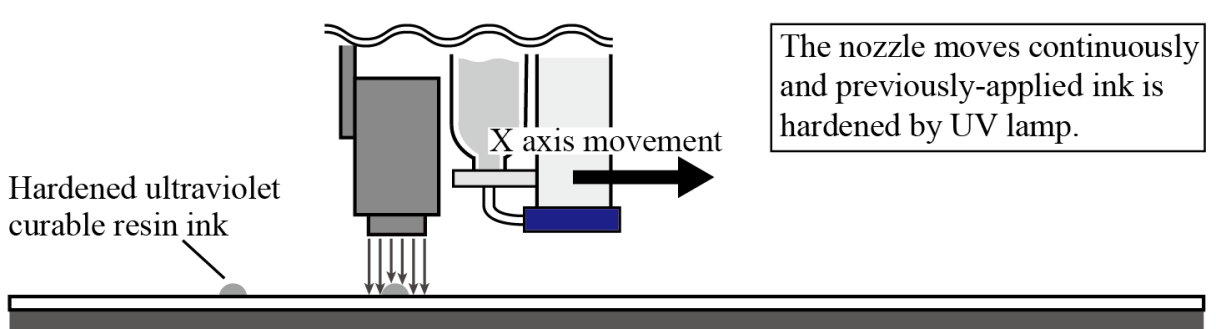

(4)

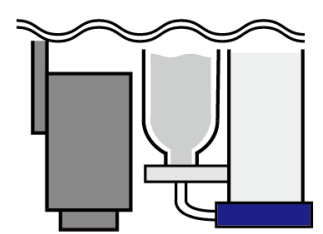

Ultraviolet curable resin ink is hardened and Braille dots is created.

Fig. 3 Process of manufacturing TRUCT Braille. 
Doi, Nishimura, Kawano, Umesawa, Matsumori, Wada and Fujimoto, Transactions of the JSME (in Japanese), Vol.81, No.831 (2015)

ンク（十条ケミカル株式会社，レイキュアーGA 4100-3 シリーズ）を詰めたノズルから，インクの塗布量を統制 しつつ, 空気圧によって非接触でインクを噴き付けて紫外線硬化樹脂点字を作成する方式を考案した. X-Y 平面 上をノズルが自由に移動できるようにリニアガイドを設置し，任意の X-Y 座標位置にインクを塗布できるように した.ノズルの X，Y 方向のそれぞれの移動はコンピュータにより位置制御を行い，ノズルの垂直方向の位置を 固定してインクを噴き付け，高速で点や線を付すことができるようにした．さらに，温度調節が可能なペルチェ 素子を備えた温度調節装置（ここでは $60^{\circ} \mathrm{C}$ ) をノズルに取り付けて周囲の温度変化によって紫外線硬化樹脂イン クの粘度が変化しないようにし, 紫外線照射ランプもノズルの側面に設置して塗布したインクを瞬時に硬化させ るようにした．点の大きさと高さは，インクの吐出量を制御することにより調節ができるようにした．具体的に は，塗布された紫外線硬化樹脂点字の高さが，先行研究（土井他，2004）において触読し易い高さであることが 示されている $0.4 \mathrm{~mm}$ になるように, 紫外線硬化樹脂インクの液送圧 $150 \mathrm{kPa}$ で内径 $0.15 \mathrm{~mm}$ のノズルのバルブシ

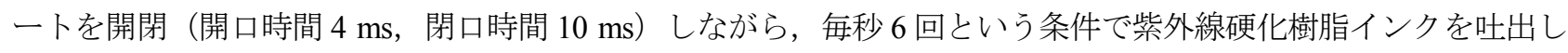
た. また, コンピュータで入力した文字を点字パターンに変換して点字が塗布できるソフトウェアを独自に作成 し，実験で採用する点字パターンを作成できるようにした.

以上のような紫外線硬化樹脂点字の作成装置を用いて, 次章で述べる実験の提示刺激を作成することにした。 なお，本装置による紫外線硬化樹脂点字の作成プロセスについては，図 3 に示寸.

\section{$2 \cdot 2$ 紫外線硬化樹脂点字の作成テスト}

次章で述べる触読性評価実験では，6 種類の文字の紫外線硬化樹脂点字を提示刺激として使用するが，実験で 設定する点間隔や高さの紫外線硬化樹脂点字を作成できるかどうかを実際に確認する必要がある，具体的には， 次章で詳述する提示刺激の中から「て」の点字（図 4）を用い，JIS T9253 の推奨值に基づき，図 5 に示す 1-2 点 間隔と 1-4 点間隔については $2.3 \pm 0.1 \mathrm{~mm}$ ，高さについては $0.4 \pm 0.1 \mathrm{~mm}$ ，直径については $1.4 \sim 1.5 \mathrm{~mm}$ を目標値 として前節で述べた紫外線硬化樹脂点字作成装置で評価サンプルを作成し, 目標值との誤差を三次元形状計測装 置（株式会社キーエンス, VR-3200）により確認した. この三次元形状計測装置の計測分解能は $1 \mu \mathrm{m}$ であった. 計測方法について述べる. まず，1-2 点間隔と 1-4 点間隔は，それぞれ点の中心間距離を計測した．点の高さと直 径は, 1 の点の高さと直径を計測した. 計測には, 5 枚の評価サンプルを用意し, 各サンプルの 1-2 点間隔, 1-4 点 間隔，高さ，直径をそれぞれ 1 回ずつ計測して平均值を算出した. その結果，表 1 に示す通り，いずれの評価項 目についても目標値通りに作成できることがわかった，なお，他の実験条件の提示刺激についても，同様の精度 で作成できることを確認した，点字の断面形状は半球状であった.

\section{$2 \cdot 3$ 小括}

本研究では, スクリーン印刷方式の問題点を改善する紫外線硬化樹脂点字の新規作成装置を製作した. 本装置 を用いることで, 実験に必要となる点間隔や高さのパターンを実現できる提示刺激が作成できることを確認した. なお，紫外線硬化樹脂点字の品質に関する JIS T9253 が推奨する点字の点間隔，高さ，直径の各サイズを満たす 紫外線硬化樹脂点字を作成することも可能であることがわかった．また，吐出条件（液送圧やノズルサイズ等）

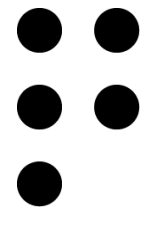

Fig. 4 "Te" in Braille.

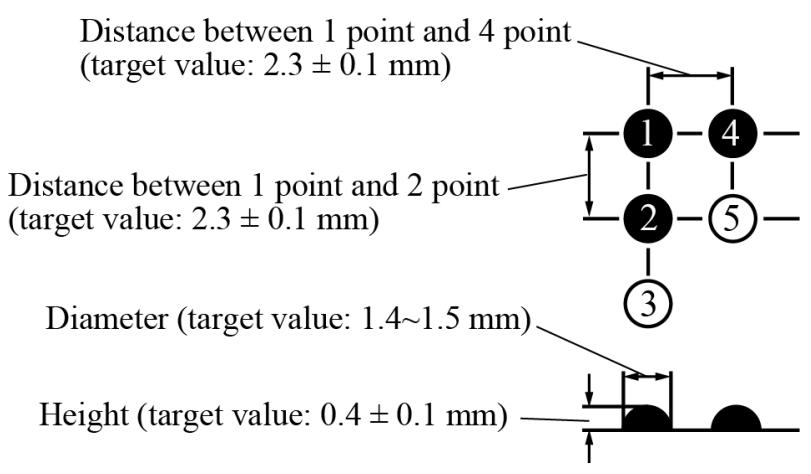

Fig. 5 Measurement item and target value. 
Doi, Nishimura, Kawano, Umesawa, Matsumori, Wada and Fujimoto,

Transactions of the JSME (in Japanese), Vol.81, No.831 (2015)

と点字の高さ等の関係を詳細に調べることで，任意のサイズの紫外線硬化樹脂点字を作成することが可能になる かという点については，今後慎重に確認をしていく必要がある.

\section{3. 触読し易い紫外線硬化樹脂点字の縦横点間隔の評価}

本章では，点字触読初心者が触読し易い紫外線硬化樹脂点字の縦横点間隔を明らかにすることを目的として， 紫外線硬化樹脂点字の縦と横それぞれの点間隔が触読性に及ぼす影響を評価した実験について述べる.

\section{$3 \cdot 1$ 実験参加者}

本実験では，点字触読初心者にとって触読し易い紫外線硬化樹脂点字の縦横点間隔を明らかにすることを目的 としている. そのため, 点字の触読経験のない晴眼者に実験参加者としての協力を得て, 実験を行うこととした. このように，点字の触読経験に関する要素を排除し，あくまでも人の指先の触知覚特性のみを踏まえて紫外線硬 化樹脂点字の点間隔と触読性の関係を評価することで，触読し易い紫外線硬化樹脂点字の点間隔に関する基礎的 知見が得られると考えられる，具体的に，実験参加者には，点字の触読経験がなく，利き手人差し指の指腹の皮 膚に外傷や関連既往症のない晴眼の成人男女 10 名の協力を得た。平均年齢は 21.5 歳（標準偏差 1.0 歳）, 利き手 は全員右手であった.

なお，本研究は，独立行政法人国立特別支援教育総合研究所倫理要項に基づき，倫理審査委員会の承認を得て 実施した。また，参加者へのインフォームドコンセントとして事前に実験内容を説明して同意を得た上で実験を 行った.

\section{$3 \cdot 2$ 提示刺激}

提示刺激として，図 6 に示すように，点字 1 文字を構成する 6 点のうちの 1 点だけが欠けた 6 種類の紫外線硬 化樹脂点字を用意した．これらの文字については，点の数が触読性に影響を及ぼし，なおかつ 6 点のうちの 5 点 から成る文字が最も読み難いという知見（佐藤，河内，2000）に基づいて決定した．この点字の作成には，前章 で述べた紫外線硬化樹脂を非接触で高精度に塗布することのできる装置を用いた．点字の点の高さは，JIS T9253

（日本規格協会，2004）で規定される範囲内にあり，なおかつ先行研究（土井他，2004）で触読し易い高さであ ることがわかっている $0.4 \mathrm{~mm}$ に統制した.

点間隔の条件については, JIS T9253 で推奨される值の下限值である $2.2 \mathrm{~mm}$ から上限值である $2.4 \mathrm{~mm}$ を条件に 含め, それよりも小さい条件と大きい条件までをカバーする範囲で選定した．また，中途視覚障害の点字学習者 を想定した紙製の $\mathrm{L}$ サイズ点字の縦横点間隔（縦点間隔 $2.7 \mathrm{~mm}$ ，横点間隔 $2.4 \mathrm{~mm}$ ）についても条件に含むよう

Table 1 Measurement results of Braille dot distance, height, and diameter.

\begin{tabular}{l|cccc}
\hline \multicolumn{1}{c|}{ Item } & $\begin{array}{c}\text { Distance between } \\
\text { 1 point and 2 point }\end{array}$ & $\begin{array}{c}\text { Distance between } \\
\text { 1 point and 4 point }\end{array}$ & Height & Diameter \\
\hline Average & 2.30 & 2.30 & 0.40 & 1.48 \\
Standard deviation & 0.02 & 0.01 & 0.01 & 0.00 \\
JIS T9253 & $2.3 \pm 0.1$ & $2.3 \pm 0.1$ & $0.4 \pm 0.1$ & $1.4 \sim 1.5$ \\
\hline
\end{tabular}

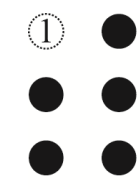

Mo

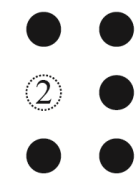

$\mathrm{Mu}$

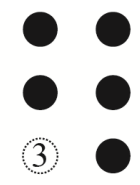

$\mathrm{Se}$

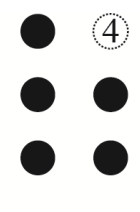

$\mathrm{Mi}$

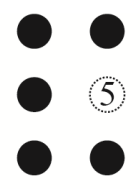

$\mathrm{He}$

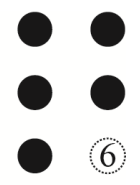

$\mathrm{Te}$

Fig. 6 TRUCT Braille used in the experiment. 
Doi, Nishimura, Kawano, Umesawa, Matsumori, Wada and Fujimoto,

Transactions of the JSME (in Japanese), Vol.81, No.831 (2015)

配慮した（日本点字普及協会，2015）。具体的には，表 2 に示す通り，縦点間隔（図 7 の 1-2 点間，2-3 点間）を 6 条件 (2.0, 2.3，2.5，2.7，2.9，3.1 [mm])，横点間隔（図 7 の 1-4 点間）を 6 条件 (2.0, 2.3, 2.5, 2.7, 2.9, $3.1[\mathrm{~mm}])$ とし，これらを組み合わせた合計 36 条件とした。

\section{$3 \cdot 3$ 評価指標とその解析方法}

本実験では，提示刺激である 1 文字の紫外線硬化樹脂点字について，いかに確信をもつて正確かつ速く触読す ることができるのかを調べるために，“正答率”, “触読時間”，“確信度”の各評価指標を採用した。正答率は，6 点のうちの欠けている点の番号を各試行後に参加者に口頭で回答させ, 参加者ごとに正答率を算出して 10 名分の データを平均した．触読時間は，次節で述べる装置を用いて計測を行い，参加者 10 名分の平均值を算出した．確 信度は，主観評価の一指標として採用し，各試行後に触読結果に対する確信の程度を 5 段階の等間隔尺度（1：確 信無し〜5:確信有り）で回答させた.

統計処理については, 各指標において対応のある 2 要因分散分析 (縦点間隔 $\times$ 横点間隔)を実施した.さらに， 下位検定として Bonferroni 法による多重比較を行い，水準間の有意差を調べた.

\section{3 - 4 触読時間の計測方法}

本実験では，図 8 に示す筆者らの自作した触読時間計測装置を用いて，触読時間を計測した．具体的な触読時 間の計測方法について述べる.まず，計測開始前は，提示刺激の上部一面に赤色半導体レーザ光が照射され，反 対側のアルミ板に結像されている状態である（図 8 (a)). そして, 実験者の合図とともに, 参加者は人差し指を 下ろして提示刺激の触読を開始する (図 8 (b))。このとき，アルミ板に結像されていた赤色半導体レーザ光は人 差し指によって遮断される. これを，触読時間の計測開始のトリガとした．提示刺激を触読している間は，アル ミ板への赤色半導体レーザ光の照射は遮断された状態が続さ, 時間計測が継続される. その後, 提示刺激の触読 が終了した時点で参加者は速やかに人差し指を上げる.このとき, 再び赤色半導体レーザ光は反対側のアルミ板 に結像する。これを，触読時間の計測終了のトリガとした (図 8 (c)).

\section{$3 \cdot 5$ 実験手順}

本実験では，実験参加者の手元をカーテンで視覚的に遮蔽し，指先で提示刺激を触察することによって得られ る触知覚上の情報のみを頼りに図 6 に示す(1)から6のうちの久けている点の番号を口頭で回答させた。具体的な

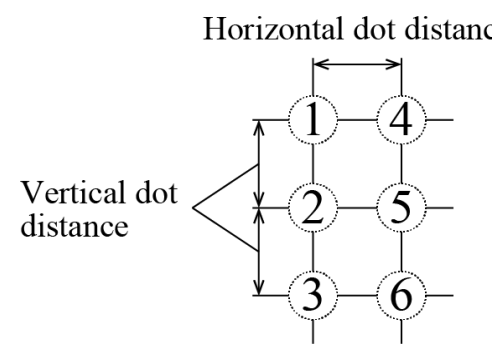

Fig. 7 Definition of dot distance.

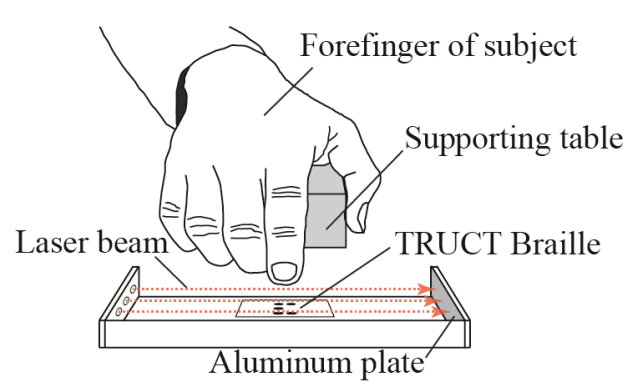

(a)

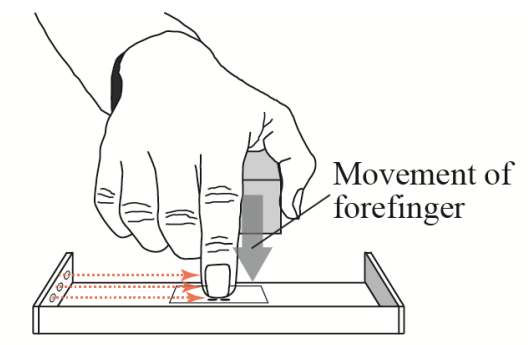

(b)

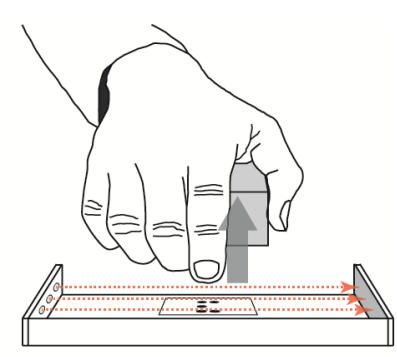

(c)

Fig. 8 Process of measuring reading time. 
Doi, Nishimura, Kawano, Umesawa, Matsumori, Wada and Fujimoto,

Transactions of the JSME (in Japanese), Vol.81, No.831 (2015)

実験手順について述べる．まず，実験装置を載せた机の前の椅子に実験参加者を座らせる．そして，参加者の手 元を視覚的に遮蔽した状態で，実験装置の前方にある台に手を置かせ，利き手の人差し指を提示刺激の上方で待 機させる．次に，実験者の開始の合図に合わせて提示刺激の触読を開始させる．この際，参加者に対して，爪を 立てずに人差し指の指腹を滑らせながら欠けている点の番号がわかるまで触読し, わかった時点で速やかに指先 を提示刺激から離すように教示をした. その後, 6 点のうちの欠けている点の番号（図 6 に示す(1)～(6)）を口頭 で回答させた．なお，本試行を行う前には，本試行で使用するものとは異なるサンプルを使って練習を行い，参 加者に実験手順について理解させた，実験は適宜休顋を取りながら行い，実験時間は各参加者ともに約 2 時間で あった。

\section{$3 \cdot 6$ 結果}

紫外線硬化樹脂点字の縦と横それぞれの点間隔が触読性に及ぼす影響を評価した実験の結果を正答率，触読時 間, 確信度の順に記す。なお, 図 9〜11 中のエラーバーは標準偏差を表す.

\section{$3 \cdot 6 \cdot 1$ 正答率}

図 9 に正答率の結果を示す. 分散分析の結果, 横点間隔の主効果が有意であった $[\mathrm{F}(5,45)=6.15, \mathrm{p}<0.01]$ が, 交互作用は認められなかった，多重比較により横点間隔における水準間の有意差を調べた結果，横点間隔が 2.3 $\mathrm{mm}$ 以上であれば, $2.0 \mathrm{~mm}$ に対して正答率は有意に高くなった $(\mathrm{p}<0.05)$.

以上の結果をまとめると，縦点間隔に関わらず，横点間隔が $2.3 \mathrm{~mm}$ 以上であれば，水準間での有意差がなく なり，正答率は一定值に収束した。

\section{$3 \cdot 6 \cdot 2$ 触読時間}

図 10 に触読時間の結果を示寸. 分散分析を実施した結果, 縦点間隔 $[\mathrm{F}(5,45)=17.32, \mathrm{p}<0.01]$ と横点間隔 $[\mathrm{F}(5$, $45)=10.97, \mathrm{p}<0.05]$ の主効果がそれぞれ有意であったが，交互作用は認められなかった．さらに，縦点間隔と横 点間隔の各要因について多重比較を行い，水準間の有意差を調べた，その結果，縦点間隔については，2.7 mm 以

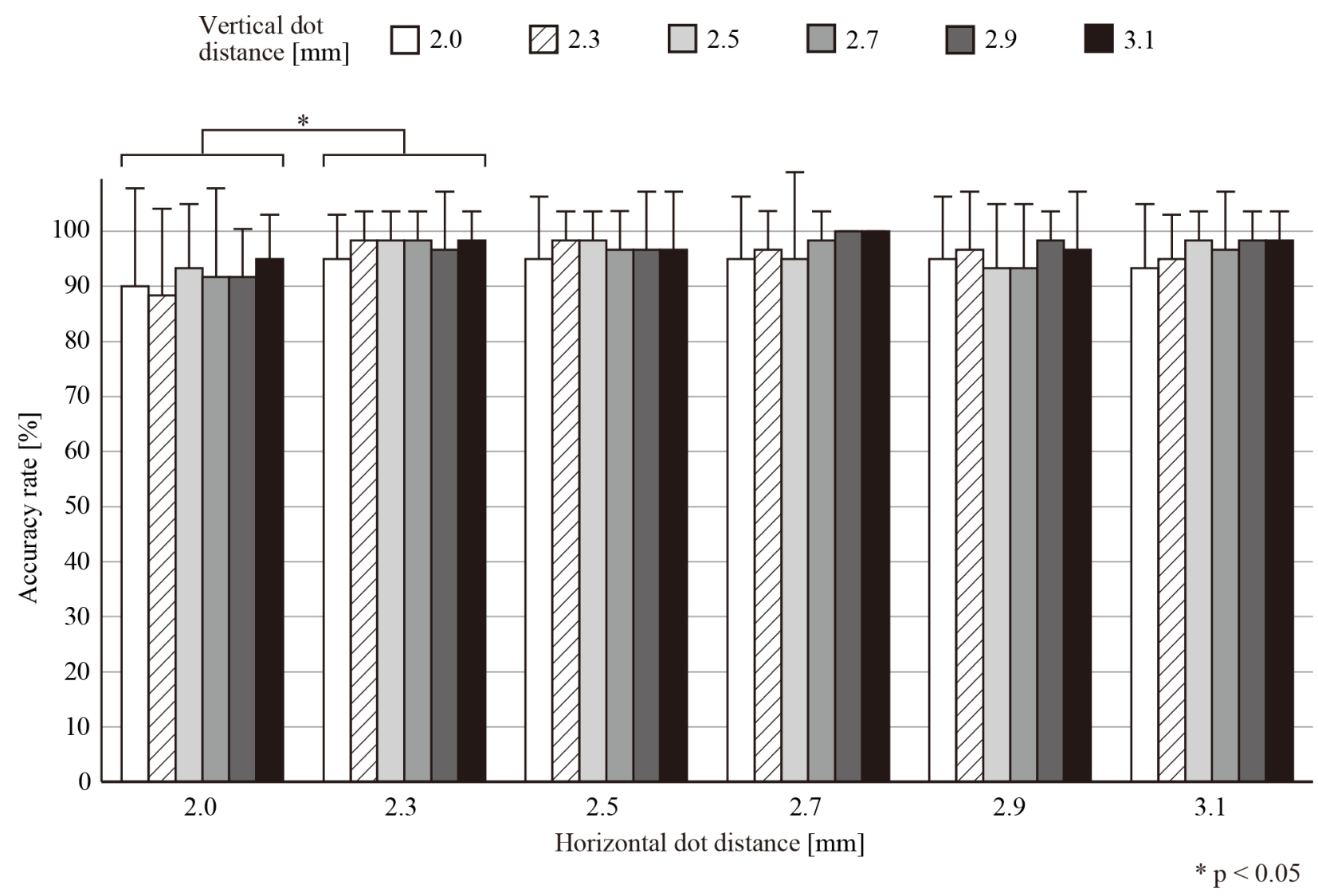

Fig. 9 Results of accuracy rate. 
Doi, Nishimura, Kawano, Umesawa, Matsumori, Wada and Fujimoto,

Transactions of the JSME (in Japanese), Vol.81, No.831 (2015)

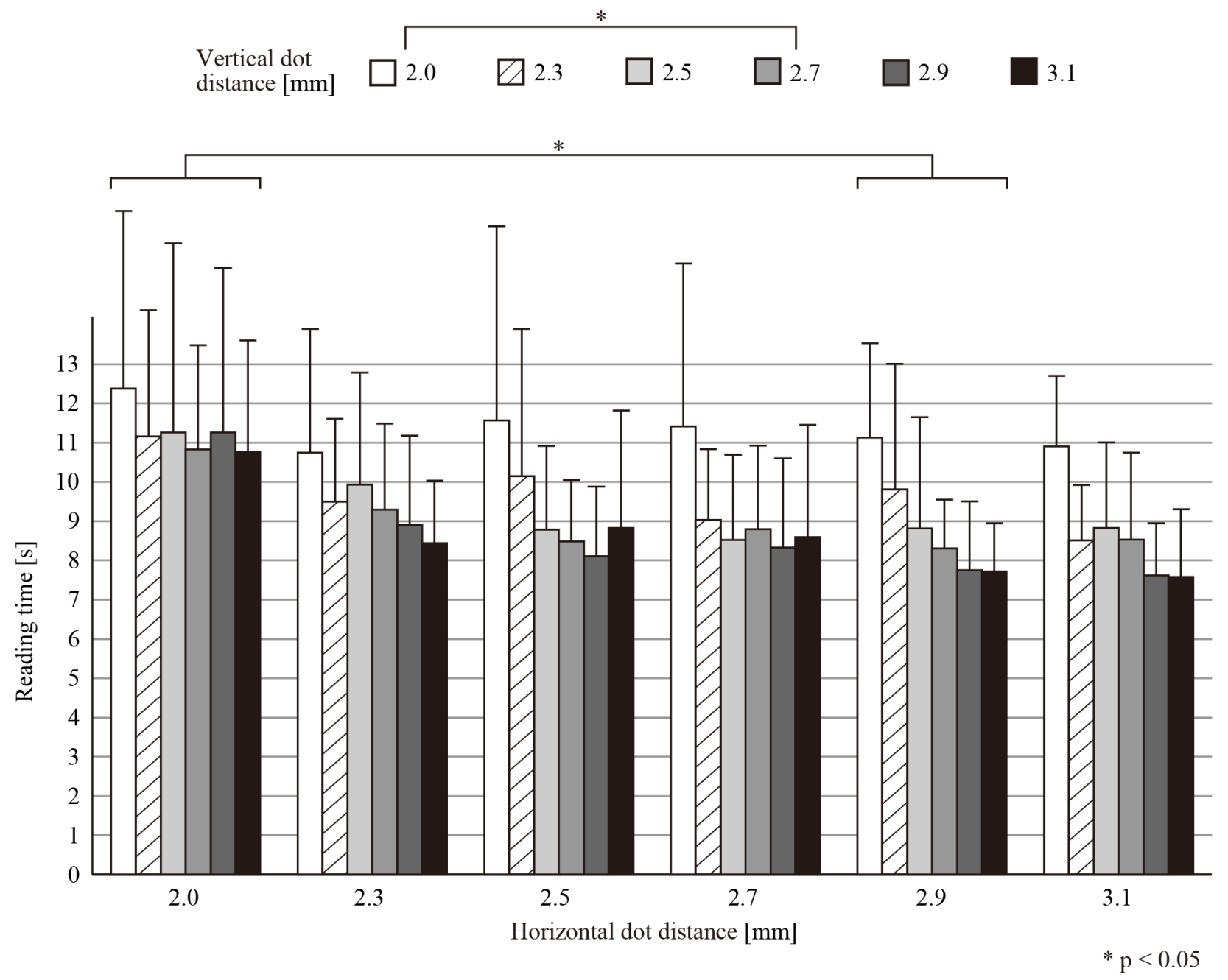

Fig. 10 Results of reading time.

上であれば， $2.0 \mathrm{~mm}$ の条件に対して触読時間は有意に短かった（ $\mathrm{p}<0.05)$. 他方，横点間隔については， $2.9 \mathrm{~mm}$ 以上にすることで, $2.0 \mathrm{~mm}$ よりも触読時間は有意に短くなった $(\mathrm{p}<0.05)$.

以上の結果をまとめると，縦点間隔を $2.7 \mathrm{~mm}$ 以上かつ横点間隔を $2.9 \mathrm{~mm}$ 以上にすることで，触読時間は有意 に短くなった。

\section{$3 \cdot 6 \cdot 3$ 確信度}

図 11 に確信度の結果を示す. 分散分析の結果, 縦点間隔 $[\mathrm{F}(5,45)=53.80, \mathrm{p}<0.001]$ と横点間隔 $[\mathrm{F}(5,45)=44.52$, $\mathrm{p}<0.001$ ] の主効果はそれぞれ有意であったが，交互作用は認められなかった．そこで，縦点間隔と横点間隔の それぞれの要因について多重比較を行い，水準間の有意差を分析した，その結果，縦点間隔については， $2.0 \mathrm{~mm}$ と $2.3 \mathrm{~mm}$ 間 $(\mathrm{p}<0.001) ， 2.3 \mathrm{~mm}$ と $2.7 \mathrm{~mm}$ 間 $(\mathrm{p}<0.01) ， 2.7 \mathrm{~mm}$ と $3.1 \mathrm{~mm}$ 間 $(\mathrm{p}<0.01 ）$ でそれぞれ有意差が

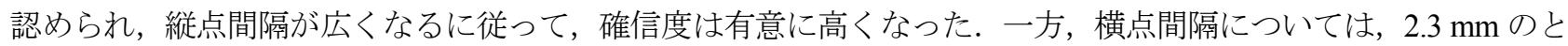
きに $2.0 \mathrm{~mm}$ よりも確信度は有意に高かった（ $\mathrm{p}<0.01 ）$. さらに, 横点間隔を $2.9 \mathrm{~mm}$ 以上にすることで, $2.3 \mathrm{~mm}$ 以下の条件よりも確信度は有意に高くなった $(\mathrm{p}<0.05)$.

以上の結果をまとめると，縦点間隔が $3.1 \mathrm{~mm}$ かつ横点間隔が $2.9 \mathrm{~mm}$ 以上であれば，確信度は一定の值に収束 した.

\section{$3 \cdot 6 \cdot 4$ 総合評価}

ここでは, 各指標で得られた結果から, 縦横点間隔が紫外線硬化樹脂点字の触読性に及ぼす影響を総合的に評 価する．まず，縦点間隔については，全体的に広くなるほど触読性は向上する傾向がみられ， $3.1 \mathrm{~mm}$ まで広くす 
Doi, Nishimura, Kawano, Umesawa, Matsumori, Wada and Fujimoto,

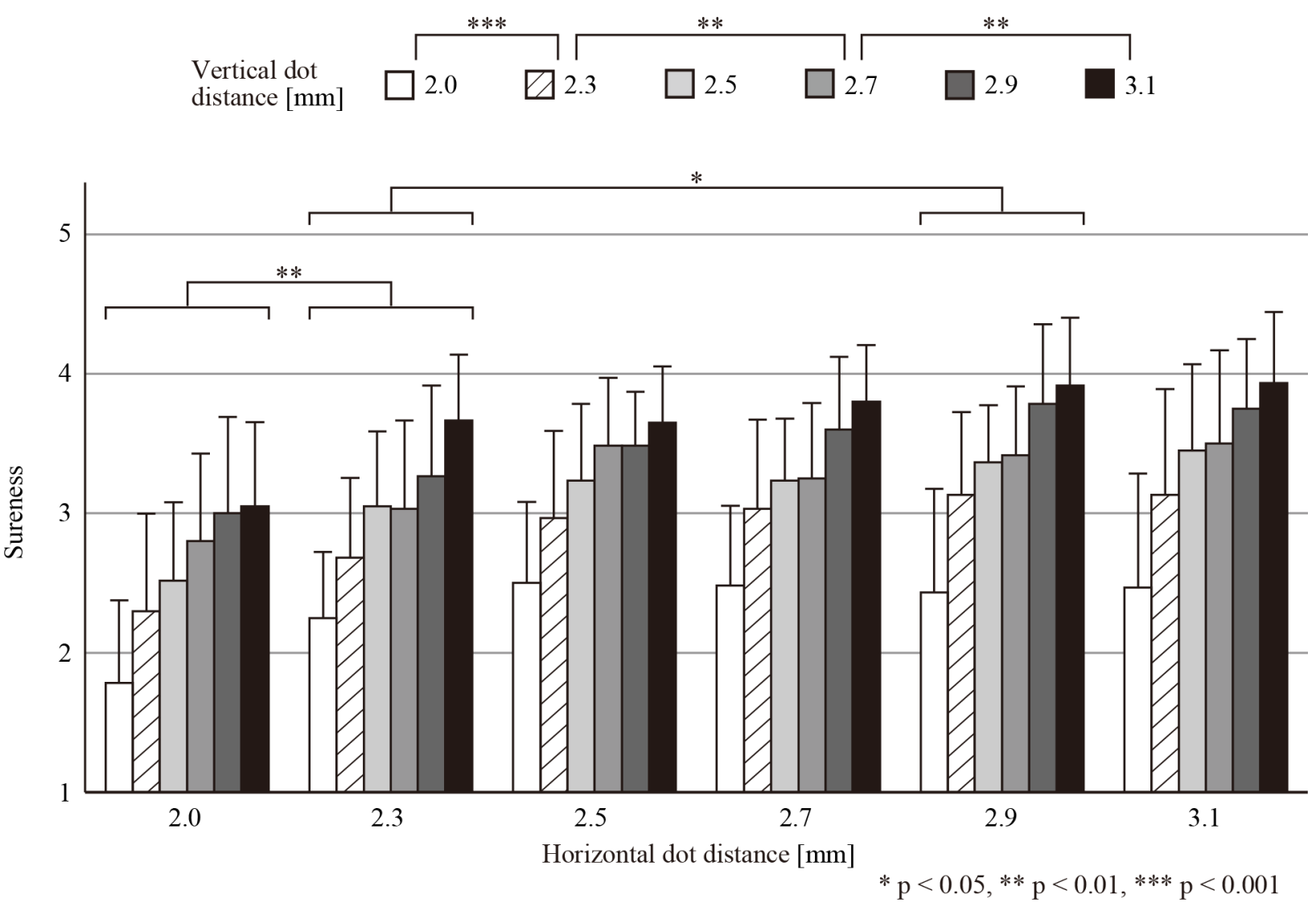

Fig. 11 Results of sureness

ることによって，有意に確信をもって速く触読できた，一方，横点間隔については，縦点間隔と同様，広くなる に従って触読性は向上寸る傾向がみられ，2.9 mm 以上にすることで，有意に確信をもって正確かつ速く触読でき た.

以上をまとめると，紫外線硬化樹脂点字の縦点間隔を $3.1 \mathrm{~mm}$ かつ横点間隔を $2.9 \mathrm{~mm}$ 以上にすることで，有意 に確信をもって正確かつ速く触読することができた.

\section{$3 \cdot 7$ 考察}

前節で述べた結果より, 紫外線硬化樹脂点字の縦点間隔を $3.1 \mathrm{~mm}$ かつ横点間隔を $2.9 \mathrm{~mm}$ 以上にすることで, 有意に確信をもって正確かつ速く触読できることがわかった。ここで，紫外線硬化樹脂点字の品質に関する JIS T9253 で推奨される点間隔の寸法を確認すると, 縦と横の点間隔ともに $2.2 \mathrm{~mm} \sim 2.4 \mathrm{~mm}$ を推奨している. 本研究 で得られた結果と比較すると，上述した JIS T9253 の推奨サイズの上限值よりも縦点間隔を $0.7 \mathrm{~mm}$ ，横点間隔を $0.5 \mathrm{~mm}$ だけ広げて点字を製作することで, 点字触読初心者にとっても読み易い紫外線硬化樹脂点字になると考え られる．なお，筆者らが過去に行った先行研究（土井他，2004）では，縦と横の点間隔の比率が 1 対 1 の条件下 で，点字触読初心者にとっても読み易い点間隔の条件を調べている．その結果，点間隔が広くなるにつれて触読 性は向上し，縦と横の点間隔がともに $2.9 \mathrm{~mm}$ であれば，速く正確に確信をもって点字を触読できることを報告 している. 本研究で得られた結果と比較すると，横点間隔を $2.9 \mathrm{~mm}$ 以上にすることで触読性が向上する点につ いては先行研究と一致する結果となったが，縦点間隔は $3.1 \mathrm{~mm}$ まで広く寸ることで確信度はさらに高くなるこ とが新たに明らかになった。このように，点字触読初心者にとって読み易い点字パターンに関する新たな知見を 獲得できたことは意義深い.

また, いずれの評価指標においても, 全体的に縦横点間隔が広がるにつれて触読性は向上寸る傾向がみられた. すなわち，縦横点間隔が狭いと触読性は低下寸ることを意味する．人の指先における空間的分解能は二点弁別閾 
Doi, Nishimura, Kawano, Umesawa, Matsumori, Wada and Fujimoto, Transactions of the JSME (in Japanese), Vol.81, No.831 (2015)

によって議論されることが多く,一般的に人の指先の二点弁別闇值は $1.0 \sim 3.0 \mathrm{~mm}$ であるといわれている (Schmidt, 1989). この数值はあくまでも静的条件下における 2 点の弁別に関する䦨值であるため, 6 点から構成される点字 を動的に触察した場合に直接的に当てはめることはできないが，縦横点間隔の值が小さく，隣り合う点同士の間 隔が狭い条件においては，複数の凸点の刺激が 1 点の刺激として感じ易くなり，欠けている点の位置の識別が難 しくなったことで, 各評価指標の值が低下した可能性は考えられる. 神経生理学的知見でも, 指腹に内包された 機械受容ユニットの発火は，刺激境界の間隔が狭くなるほど区別し難くなることが報告されており，本研究でみ られた傾向を支持する（Blake et al., 1997）.

\section{$3 \cdot 8$ 小括}

本実験では，点字触読初心者にとって触読し易い紫外線硬化樹脂点字の縦横点間隔の条件を明らかにすること ができた。ここで得られた知見が点字触読初心者の使用寸る点字学習教材等に活用されることで，点字習得の八 ードルが少しでも下がることを期待したい. なお，紫外線硬化樹脂点字の触読性に影響を及ぼす因子の中で，行 間隔については，これまでに点字触読初心者にとって読み易い条件はほとんど調べられていない. しかし，点字 で文章を触読する際には，行の間に適切な間隔が設けられていないと，文章の触読は困難になると考えられる. そのため，今後は行間隔についても同様な評価実験を行い，点字触読初心者にとって読み易い行間隔の条件を明 らかにしていくことが必要であると考えられる.

\section{4. 結言}

本研究では，スクリーン印刷方式の技術的課題への対応及び点字触読初心者が触読し易い紫外線硬化樹脂点字 パターン（縦横点間隔）を明らかにすることを目的として，新たな紫外線硬化樹脂点字の作成装置の製作及び紫 外線硬化樹脂点字の縦横点間隔が触読性に及ぼす影響を評価した。具体的に，装置製作においては，厚盛りが可 能で仕上がりの良い新たな紫外線硬化樹脂点字作成装置として, JIS T9253 に示される点字の高さの推奨值で安定 して点字を作成可能な装置を製作し，その装置を用いて実験に必要な提示刺激を作成することができた．なお， 紫外線硬化樹脂点字の品質に関寸る JIS T9253 が推奨する点字の点間隔や高さ等のサイズを満たす紫外線硬化樹 脂点字を作成することも可能であることがわかった．そして，点字の触読に不慣れな点字触読初心者にとって読 み易い縦横点間隔の条件を明らかにするために, 点字の触読経験がない晴眼者を対象とした紫外線硬化樹脂点字 の触読実験を実施した，その結果，点字触読初心者にとって触読し易い紫外線硬化樹脂点字の縦横点間隔の条件 を明らかにすることができた. 本研究で得られた知見が点字触読初心者向けの点字学習教材等に活かされること で，点字学習環境が改善することを期待したい.

\section{文献}

Blake, D. T., Hsiao, S. S. and Johnson, K. O., Neural coding mechanisms in tactile pattern recognition: the relative contributions of slowly and rapidly adapting mechanoreceptors to perceived roughness, The Journal of Neuroscience, Vol.17 (1997), pp.7480-7489.

土井幸輝, 小田原利江, 林美恵子, 藤本浩志, UV 点字パターンの識別容易性評価に関する研究, 日本機械学会論 文集 C 編, Vol.70, No.699 (2004), pp.300-305.

土井幸輝, 岩崎业紀, 藤本浩志, 印刷素材が UV 点字の触読性に及ぼす影響に関する研究, 日本機械学会論文集 C 編, Vol.72, No.716 (2006), pp.216-222.

土井幸輝, 西村崇宏, 藤本浩志, 和田勉, 田中良広, 澤田真弓, 大内進, 金子健, 金森克浩, 紫外線硬化樹脂点字の マス間隔比が触読性に及ぼす影響, 国立特別支援教育総合研究所研究紀要, Vol.41 (2014), pp.27-36.

林美恵子, 鴨田真理沙, 藤本浩志, 識別しや寸い点字の形状に関する研究, 人間工学, Vol.39, No.3 (2003), pp.117-122.

日本規格協会, JIS T9253(紫外線硬化樹脂インキ点字一品質及び試験方法) (2004).

日本点字普及協会, L サイズ点字とは, <http://tenjifukyu.jp/activity/l-size/> (2015), (参照日 2015 年 7 月 3 日).

厚生労働省社会・援護局障害保健福祉部企画課, 平成 18 年身体障害児・者実態調査結果 (2006), p.24.

佐藤将朗, 河内晴彦, 能動的触察条件における点字レジビリティ一の検討, 特殊教育学研究, Vol.38, No.2 (2000), 
Doi, Nishimura, Kawano, Umesawa, Matsumori, Wada and Fujimoto,

pp.53-61.

Schmidt, R.F. (編), 感覚生理学 (1989), 金芳堂.

渡辺哲也，大内進，土井幸輝，点間隔を広げた点字の読みやすさに関する研究，電子情報通信学会誌 D 編. Vol. J94-D, No.1 (2011), pp.191-198.

\section{References}

Blake, D. T., Hsiao, S. S. and Johnson, K. O., Neural coding mechanisms in tactile pattern recognition: the relative contributions of slowly and rapidly adapting mechanoreceptors to perceived roughness, The Journal of Neuroscience, Vol.17 (1997), pp.7480-7489.

Doi, K., Odawara, R., Hayashi, M. and Fujimoto, H., The influence of the patterns of Transparent-Resinous-Ultraviolet-Curing-Type Braille on the discriminability, Transactions of the Japan Society of Mechanical Engineers, Series C, Vol.70, No.699 (2004), pp.300-305 (in Japanese).

Doi, K., Iwasaki, A. and Fujimoto, H., Influence of base material on Transparent-Resinous-Ultraviolet-Curing-Type Braille reading, Transactions of the Japan Society of Mechanical Engineers, Series C, Vol.72, No.716 (2006), pp.216-222 (in Japanese).

Doi, K., Nishimura, T., Fujimoto, H., Wada, T., Tanaka, Y., Sawada, M., Oouchi, S., Kaneko, T. and Kanamori, K., Influence of character spacing ratio on TRUCT Braille readability, Bulletin of The National Institute of Special Needs Education, Vol.41 (2014), pp.27-36 (in Japanese).

Hayashi, M., Kamota, M. and Fujimoto, H., The influence of shapes of Braille on the distinguishability, The Japanese Journal of Ergonomics, Vol.39, No.3 (2003), pp.117-122 (in Japanese).

Japanese Standards Association, JIS T9253 (Performance and test method of ultraviolet ray hardening resinous braille) (2004) (in Japanese).

Japanese Association for Braille Promotion, What is L size Bralle?, available from <http://tenjifukyu.jp/activity/l-size/> (2015), (accessed on 3 July, 2015) (in Japanese).

Policy Planning Division, Department of Health and Welfare for Persons with Disabilities, Ministry of Health, Labour and Welfare, Survey on persons with pyhsical disability (2006), p.24 (in Japanese).

Sato, M. and Kawauchi, K., Legibility of Japanese Braille, The Japanese Journal of Special Education, Vol.38, No.2 (2000), pp.53-61 (in Japanese).

Schmidt, R.F. ed., Fundamentals of sensory physiology (1989), Kinpodo (in Japanese).

Watanabe, T., Oouchi, S. and Doi, K., A study on legibility of enlarged Braille, The IEICE transactions on information and systems, Vol.J94-D, No.1 (2011), pp.191-198 (in Japanese). 